\title{
POZORNOŚĆ UMOWY O PRACĘ W PRZYPADKU ZATRUDNIENIA ZEWNĘTRZNEGO
}

\begin{abstract}
Abstrakt: Pozorność umowy o pracę wymaga tajnego porozumienia między pracodawcą a pracownikiem co do symulowanej czynności. Pracownik nie może domyślać się rzeczywistych intencji pracodawcy, a jego zgoda na pozorowaną czynność musi być niewątpliwa. Nie sposób przypisać pracownikowi zgody na pozorny stosunek pracy, gdy przystępuje on w dobrej wierze do wykonania umowy przez świadczenie pracy na rzecz osoby trzeciej. Fakt wykonywania pracy na rzecz podmiotu innego niż pracodawca, oceniany ex post, nie tylko mógłby wpływać na rzeczywiste intencje pracownika, lecz także może stanowić o modyfikacji umowy. Odrzucenie tej perspektywy dla sprawniejszego zakwestionowania umowy o pracę z uwagi na sugerowaną pozorność należy uznać za błąd w stosowaniu prawa. W szczególności $\mathrm{w}$ trwałych stosunkach prawnych warto pamiętać o wykładni adaptacyjnej, uwzględniającej zmiany stosunków prawnych w czasie, w tym modyfikacje wyrażające się w obiektywnie ocenionym następczym zachowaniu stron oraz osób trzecich.

Słowa kluczowe: pozorne oświadczenie woli, pracodawca zewnętrzny, wykładnia umowy, dorozumiane nawiązanie stosunku pracy
\end{abstract}

\section{WPROWADZENIE}

Zagadnienie pozorności w umownych stosunkach pracy jest szeroko omawiane w literaturze oraz orzecznictwie ${ }^{1}$. Jako wada oświadczenia woli, będąca podstawą nieważności czynności prawnej, jest instrumentem o dużej doniosłości praktycznej.

Analizując najczęściej występujące w obrocie prawnym przypadki, można wskazać trzy typowe sytuacje wymagające rozważenia ważności umowy o pracę z perspektywy art. 83 k.c. Po pierwsze, symulowanie zawarcia umowy cywilnoprawnej dla ukrycia innej czynności prawnej - umowy o pracę². Po drugie,

1 Przykładowo: M. Raczkowski, Pozorność w umownych stosunkach pracy, Warszawa 2010; K. Ślebzak, Kontrola przez ZUS ważności umów o pracę stanowiacych tytuł do ubezpieczenia spotecznego - wybrane zagadnienia, „Praca i Zabezpieczenie Społeczne” 2017, nr 2.

2 Por. między innymi wyroki Sądu Najwyższego: z 2 grudnia 2009 roku, I PK 123/09, OSNP 2011, nr 11-12, poz.152; z 10 lipca 2019 roku, III PK 87/18, LEX nr 2692795; z 30 września 2020 roku, I UK 51/19, LEX nr 3077394. 
zawarcie umowy o pracę w warunkach pozorności bezwzględnej, przez ujawnienie jedynie formalnego wyrazu oświadczeń woli bez rzeczywistego wykonywania umowy $^{3}$. Po trzecie, zawarcie umowy o pracę o symulowanej treści, w celu ukrycia rzeczywistej skali zobowiązania, co daje podstawy do uznania, że formalnie zawarta umowa jest częściowo pozorna ${ }^{4}$.

W typowej sytuacji faktycznej, wymagającej oceny pod kątem pozorności oświadczeń woli, rozważa się pojedynczą czynność prawną, wszak tajne porozumienie obejmuje strony czynności pozorowanej. Należy jednak mieć na uwadze, że oceniana czynność może pozostawać w związku z inną umową o odmiennym układzie podmiotowym, a pozorność nie powinna być odnoszona do odizolowanych oświadczeń woli, lecz musi obejmować kompleks umów i być umiejscowiona w danym kontekście sytuacyjnym.

Ustalenie, że podejrzewana o pozorność umowa o pracę funkcjonuje w obrocie prawnym w kontekście szerszego porozumienia, pociąga dodatkowe problemy interpretacyjne, dotyczące chociażby osoby trzeciej, na której rzecz praca ma być wykonywana.

Rozpatrzmy następującą sytuację: przedsiębiorca decyduje się na wyodrębnienie określonych zadań związanych z prowadzoną działalnością (przykładowo obsługą ciągu produkcyjnego), których realizację powierza podmiotowi zewnętrznemu, wykonującemu zlecenie przy pomocy kadry pracowniczej, którą dysponuje bądź którą uzyska. W celu wywiązania się z zobowiązania podmiot zewnętrzny nawiązuje umowę o pracę, której przedmiotem jest wykonanie czynności w miejscu i na rzecz przedsiębiorcy, który decyduje się na ,zatrudnienie zewnętrzne”. Kontekst prawny uzupełnia fakt wykonywania czynności na rzecz przedsiębiorcy pod jego nadzorem i w wyznaczonym przezeń miejscu oraz czasie. Nakreślone relacje można sklasyfikować jako: umowę o pracę zawartą między pracodawcą zewnętrznym a pracownikiem; umowę o współpracę między pracodawcą zewnętrznym a przedsiębiorcą (osobą trzecią z perspektywy umowy o pracę) oraz ,faktycznie realizowaną pracę" na rzecz przedsiębiorcy. Taki układ jest charakterystyczny dla agencji pracy tymczasowej, przy czym dostrzec można propagowany w obrocie zbliżony model biznesowy ujmowany jako ,zatrudnienie zewnętrzne"5.

3 Por. między innymi wyroki Sądu Najwyższego: z 18 maja 2006 roku, II UK 164/05, LEX nr 192462; z 5 października 2006 roku, I UK 120/06, OSNP 2007, nr 19-20, poz. 294; z 22 czerwca 2015 roku, I UK 367/14, LEX nr 1771586; z 25 kwietnia 2019 roku, I UK 44/18, LEX nr 2652514.

4 Por. między innymi wyroki Sądu Najwyższego z 6 października 2004 roku, I PK 545/03, OSNP 2005, nr 24, poz. 388; z 14 marca 2014 roku, II PK 160/13, LEX nr 1458631; oraz wyrok Sądu Apelacyjnego w Łodzi z 21 lutego 2017 roku, III AUa 245/16, LEX nr 2278239.

${ }^{5}$ Niniejsza analiza nie obejmuje zagadnienia nieważności czynności prawnej, zmierzającej do obejścia prawa w kontekście modelu biznesowego analogicznego do funkcjonowania agencji pracy tymczasowej, por. A. Miętek, Zatrudnienie zewnętrzne a swoboda umów stron stosunku pracy analiza zjawiska, „Monitor Prawa Pracy” 2015, nr 10. 
Nasuwa się pytanie, czy pracodawca zawierający umowę o pracę wyłącznie w celu realizacji umowy zawartej z osobą trzecią, która zakłada zobowiązanie do świadczenia pracy przy pomocy zewnętrznej siły roboczej na rachunek i pod nadzorem osoby trzeciej, jest dla zatrudnionego pracownika pracodawcą rzeczywistym? Czy umowa o pracę zawarta w wyżej zakreślonym kontekście może być uznana za pozorną?

\section{POZORNOŚĆ JAKO TAJNE POROZUMIENIE STRON CZYNNOŚCI PRAWNEJ}

Pozorność jest wadą oświadczenia woli polegającą na niezgodności między aktem woli a jej przejawem na zewnątrz, przy czym strony zgodne są co do tego, aby wspomniane oświadczenie nie wywołało skutków prawnych ${ }^{6}$. O pozorności oświadczeń woli można mówić wtedy, gdy wystąpią łącznie trzy warunki: oświadczenie woli musi być złożone tylko dla pozoru, oświadczenie woli musi być złożone drugiej stronie, adresat oświadczenia woli musi zgadzać się na dokonanie czynności prawnej jedynie dla pozoru 7 . Jedną z postaci wady pozorności jest pozorność czysta (bezwzględna), gdy strony dokonują czynności prawnej, nie mając zamiaru wywołania żadnych skutków prawnych. Oświadczenie woli stron nie może wtedy wywoływać skutków prawnych odpowiadających jego treści, ponieważ same strony tego nie chcą. Najczęściej jednak czynność pozorowana ma na celu ukrycie innej - rzeczywistej i zamierzonej — czynności prawnej (pozorność kwalifikowana). W tym przypadku adresat pozornego oświadczenia woli nie tylko zgadza się na symulowanie, ale także działa z wolą ukrycia innej czynności prawnej ${ }^{8}$. Rzeczywistym zamiarem stron jest wywołanie innych skutków, niż wynikałoby to z ujawnionych oświadczeń. W wypadku pozorności kwalifikowanej spełnienie świadczenia nie przesądza jeszcze o braku pozorności umowy9.

Obie formy pozorności wymagają, by strony umowy symulowanej działały w tajnym porozumieniu, którego koniecznym warunkiem jest zgoda adresata pozornego oświadczenia woli. Adresat musi mieć pozytywną wiedzę, że oświadczenie nie ma wywołać skutków prawnych, jakie normalnie z niego wynika-

${ }^{6}$ Por. wyroki Sądu Najwyższego z 23 czerwca 1986 roku, I CR 45/86, LEX nr 8766, oraz z 28 kwietnia 2016 roku, I UK 156/15, OSNP 2017, nr 12, poz. 166.

7 Z. Radwański, M. Gutowski, Wady oświadczeń woli, [w:] System Prawa Prywatnego, t. 2. Prawo cywilne - część ogólna. red. Z. Radwański, A. Olejniczak, Warszawa 2019, s. 495. Tak też między innymi w wyroku Sądu Najwyższego z 2 marca 2016 roku, V CSK 397/15, LEX nr 2032328.

8 Por. wyrok Sądu Najwyższego z 28 kwietnia 2016 roku, I UK 156/15, OSNP 2017, nr 12, poz. 166.

9 Por. wyrok Sądu Najwyższego z 2 marca 2016 roku, V CSK 397/15, LEX nr 2096150. 
ją i musi na taki stan wyrazić niebudzącą wątpliwości zgodę ${ }^{10}$. Jak podkreśla B. Lewaszkiewicz-Petrykowska, nie mieści się w pojęciu zgody sytuacja, gdy adresat oświadczenia woli domyśla się, zorientował się albo powinien zorientować się o zamiarze pozorności ${ }^{11}$.

Przenosząc powyższe ustalenia na sytuację opisaną uprzednio, należy dostrzec wymóg zgody pracownika na symulowanie zawarcia umowy o pracę z danym podmiotem jako pracodawcą. Tajne porozumienie obejmuje wolę co do tego, że osoba określona w umowie jako pracownik nie będzie świadczyć pracy na rzecz pracodawcy, a osoba określona jako pracodawca nie będzie korzystać z jego pracy, czyli gdy strony z góry zakładają, że nie będą realizowały swoich praw i obowiązków wypełniających treść stosunku pracy. Trudność sprawia jednak wykazanie wyżej rozumianej zgody w przypadku spełnienia świadczenia, lecz nie na rzecz formalnego pracodawcy, ale na rzecz osoby trzeciej. Z perspektywy pracownika świadczenie, do którego się zobowiązał, jest wykonywane, przy czym wobec innego podmiotu niż strona umowy o pracę. Charakter relacji z osobą trzecią może w toku wykonania umowy się zmienić, między innymi przez stopniowe intensyfikowanie aspektów pracowniczego podporządkowania. W toku świadczenia pracy ujawnić się może podmiot rzeczywiście korzystający z atrybutów pracodawcy, bieżąco kierujący pracą i ponoszący ryzyka związane z zatrudnieniem.

Zastosowanie omawianej wady oświadczenia woli do oceny umowy o pracę wymaga konfrontacji z zasadami prawa pracy w myśl art. 300 k.p. Kodeks pracy fragmentarycznie reguluje kwestię pozorności (art. $\left.22 \S 1^{1} \mathrm{i} \S 1^{2} \mathrm{k} . \mathrm{p}.\right)$, co uzasadnia odpowiednie stosowanie przepisów kodeksu cywilnego z uwzględnieniem zasad prawa pracy ${ }^{12}$. Zasady prawa pracy nie dają jednak podstaw do modyfikacji norm wyrażonych w art. $83 \S 1$ k.c. Tym samym nie sposób przyjąć łagodniejszych kryteriów przy wykładni zwrotu ,za zgodą drugiej strony”. Także w wypadku pracownika zgoda na pozorowanie czynności prawnej nie może być domniemywana. Nie może być jedynie uzasadnioną wątpliwością pracownika co do symulacji stosunku pracy. W opisanym przypadku trudno nawet stawiać pracownikowi zarzut braku staranności w ocenie sytuacji prawnej, skoro świadczenie pracy w ramach stosunku pracy na rzecz podmiotu innego niż pracodawca jest co do zasady prawnie dopuszczalne ${ }^{13}$.

10 Por. wyroki Sądu Najwyższego: z 25 lutego 1998 roku, II CKN 816/97, LEX nr 56813; z 11 maja 2016 roku, I CSK 326/15, LEX nr 2096150.

11 B. Lewaszkiewicz-Petrykowska, Wady oświadczenia woli w polskim prawie cywilnym, Warszawa 1973, s. 59.

12 M. Raczkowski, Pozorność w umownych stosunkach..., s. 84-85; M. Lewandowicz-Machnikowska, Wady oświadczenia woli, [w:] System Prawa Pracy, t. 1. Część ogólna, red. K.W. Baran, Warszawa 2017, s. 105.

13 Por. wyroki Sądu Najwyższego: z 7 maja 1998 roku, I PKN 71/98, OSNP 1999, nr 8, poz. 282; z 5 listopada 1999 roku, I PKN 337/99, OSNP 2001, nr 6, poz. 186; z 8 lipca 2015 roku, II PK 282/14, OSNP 2017, nr 6, poz. 66. 
Symulowany bądź rzeczywisty charakter oświadczeń woli należy oceniać na moment ich składania. Tajne porozumienie stron co do pozorowania czynności prawnej powinno być uzgodnione najpóźniej w chwili jej dokonania ${ }^{14}$. W tym kontekście należy raz jeszcze zaznaczyć, że zgoda nie może być utożsamiana z sytuacją, w której pracownik domyśla się, iż zawarta przez niego umowa o pracę może być fikcyjna, gdyż w rzeczywistości świadczyć będzie pracę na rzecz osoby trzeciej. Z pola widzenia nie może również umykać fakt, że wykreowany w momencie składania oświadczeń woli stosunek zobowiązaniowy może w toku jego wykonywania się zmieniać. Prawo nie zabrania, aby strony przez późniejsze zachowania zawarły nową, modyfikującą pierwotną, umowę ${ }^{15}$. Dodatkowo wiedza pracownika o rzeczywistych warunkach świadczonej pracy może w toku wykonywania umowy się zmienić.

Tak nakreślona perspektywa komplikuje możliwość dokonania oceny zgody pracownika na symulowanie stosunku pracy na moment zawarcia umowy o pracę. Zafałszowaniem oceny byłoby uwzględnienie jako rozstrzygającej relacji stron po zawarciu umowy.

Powyższe rozważania służą uprawdopodobnieniu tezy, że w przypadku braku możliwości wykazania, choćby dowodami pośrednimi ${ }^{16}$, iż najpóźniej w chwili zawarcia umowy o pracę pracownik wyrażał niewątpliwą zgodę na symulowanie zatrudnienia, nie można ocenić wskazanej czynności prawnej jako obarczonej pozornością. Brak ustalenia wspólnego, tajnego porozumienia między stronami umowy o pracę wyklucza zastosowanie przepisu art. $83 \S 1$ k.c., zarówno w przypadku pozorności bezwzględnej, jak i kwalifikowanej.

W literaturze zaznacza się, że złożenie oświadczenia woli bez zamiaru wywołania skutków prawnych, jednakże bez powiadomienia o tym drugiej strony, czyli reservatio mentalis, nie stanowi pozorności ${ }^{17}$. Nie ma żadnego znaczenia potajemne zastrzeżenie polegające na zewnętrznym wyrażeniu woli, jakiej w rzeczywistości osoba składająca oświadczenie nie miała, gdy adresat oświadczenia nie wie o tym zastrzeżeniu potajemnym, podobnie jak wewnętrzne zastrzeżenie kontrahenta, że zobowiązania z zawartej umowy nie dotrzyma ${ }^{18}$. R. Longchamps de Berier wskazywał, że zastrzeżenie potajemne musi pozostać bez znaczenia dla

14 B. Lewaszkiewicz-Petrykowska, [w:] Kodeks cywilny. Komentarz. Część ogólna, red. P. Księżak, M. Pyziak-Szafnicka, Warszawa 2014, s. 971.

15 Z. Radwański, Zagadnienia ogólne wykładni oświadczeń woli, „Nowe Prawo” 1986, z. 9, s. 32 .

16 Wykazane każdym środkiem dowodowym okoliczności zawarcia umowy, relacje między stronami poprzedzające zawarcie umowy, domniemania faktyczne itp. Por. między innymi w wyrokach Sądu Najwyższego: z 2 października 2008 roku, II CSK 208/08, LEX nr 512975; z 14 marca 2014 roku, II PK 160/13, LEX nr 1458631; z 11 maja 2016 roku, I CSK 326/15, LEX nr 2096150.

17 B. Lewaszkiewicz-Petrykowska, [w:] Kodeks cywilny. Komentarz, s. 967; a także idem, Wady oświadczenia woli..., s. 55.

${ }^{18}$ K. Piasecki, [w:] Kodeks cywilny. Księga pierwsza. Część ogólna. Komentarz, Kraków 2003, s. 409-410. 
ważności czynności prawnej, gdyż inaczej zachwiana byłaby pewność obrotu, której wskazany autor przypisał kardynalne znaczenie dla porządku prawnego ${ }^{19}$. Powyższy pogląd zachowuje aktualność także wówczas, gdy składający oświadczenie woli chce wywołać inne skutki prawne niż powiązane z formalnie dokonaną czynnością prawną.

Zaistniałą rozbieżność między oświadczeniem pozornego pracodawcy a oświadczeniem pracownika można by spróbować rozwiązać w drodze wykładni. Ten sposób może okazać się jednak nieskuteczny. Podkreślić należy za Z. Radwańskim, że nie jest przedmiotem wykładni „,rzeczywista wola” składającego oświadczenie $\mathrm{i}, \mathrm{w}$ konsekwencji, nie jest zadaniem interpretatora ustalenie takiej woli. W przeciwnym razie pojawiłaby się sprzeczność między innymi z powszechnie akceptowanym poglądem, że tylko manifestowane w sposób dostrzegalny dla innych osób zachowania mogą mieć doniosłość prawną, a w szczególności należeć do klasy oświadczeń woli ${ }^{20}$. Tym samym przedmiotem interpretacji powinno być to, co pozorny pracodawca oświadczył pracownikowi jawnie, nie zaś to, co pod osłoną danej czynności zamierzał osiągnąć. Jedynie w sferze manifestowanego oświadczenia woli można uwzględnić zgodny zamiar stron, którego wyjaśnienie stanowi istotę wykładni.

Powyższe argumenty dają podstawę do przyjęcia, że pozorne oświadczenie pracodawcy, który mimo nawiązania stosunku pracy nie realizuje właściwych stronie umowy o pracę zadań, dopuszczając, by praca była wykonywana na rzecz i pod kierownictwem osoby trzeciej, nie może stanowić o nieważności umowy o pracę z powodu jej pozorności. Dodatkowo, kwalifikacja zawartej umowy w świetle złożonych oświadczeń woli oraz okoliczności im towarzyszących musi odbywać się na podstawie zewnętrznie zamanifestowanej woli. Tym samym pozornie złożone oświadczenie o zatrudnieniu, zaakceptowane przez nieświadomego pozoru pracownika, kreuje w chwili złożenia oświadczeń woli ważne zobowiązanie - stosunek pracy.

\section{NASTĘPCZE ZACHOWANIE STRON UMOWY}

W następstwie zawartej umowy pracownik podejmuje się świadczenia pracy na rzecz osoby trzeciej. W trakcie realizacji umowy warunki wykonywanej pracy mogą się zmienić, przez zintensyfikowanie nadzoru ze strony osoby trzeciej i ujawnienie rzeczywistego podmiotu zatrudniającego (na którego rzecz praca podporządkowana jest wykonywana). Podmiot zobowiązany do zastosowania prawa materialnego, ustalając powyższe okoliczności faktyczne ex post, winien roz-

19 R. Longchamps de Berier, Zobowiazania, Lwów 1938, s. 79.

20 Z. Radwański, Wykładnia oświadczeń woli składanych indywidualnym adresatom, Wrocław 1992, s. 74. 
ważyć, czy następcze zachowanie strony umowy urzeczywistnia intencje, jakimi kierowała się w chwili jej zawarcia, czy też stanowi ono dowód złożenia nowego dorozumianego oświadczenia woli, modyfikującego pierwotne zobowiązanie ${ }^{21}$.

Przyjęcie, że każdorazowo następcze zachowanie stron dowodzi rzeczywistej woli składających oświadczenia, stoi w sprzeczności z art. $65 \S 1$ k.c., zobowiązującym do uwzględnienia całokształtu okoliczności w celu odtworzenia treści oświadczenia ex tunc, a więc przy uwzględnieniu logicznych, obiektywnie ocenionych relacji zachodzących zarówno przed, jak i w chwili zawierania umowy.

$\mathrm{W}$ doktrynie prawa cywilnego zwrócono uwagę na swoistość wykładni oświadczeń woli kształtujących stosunki trwałe (takie jak stosunek pracy). W tym przypadku uzasadniona wydaje się wykładnia adaptacyjna, biorąca pod uwagę zmianę stosunków w czasie ${ }^{22}$. Uwzględnienie zróżnicowanego zachowania stron umowy w czasie nie musi wpływać na wykładnię pierwotnych oświadczeń woli, lecz może dowodzić faktu złożenia późniejszego oświadczenia, modyfikującego bądź niwelującego umowę pierwotnąa ${ }^{23}$. Rzecz jasna, późniejsze oświadczenie woli musiałoby zostać odtworzone przy pomocy kryteriów wskazanych w art. 65 k.c., w ramach kontekstu czynności podejmowanych i akceptowanych przez pracownika w relacji do osoby trzeciej.

Na kontekst ów wpłynąć może fakt uprzednio zawartej umowy o pracę. W ujęciu subiektywnym świadczona przez pracownika w dobrej wierze na rzecz osoby trzeciej praca mogłaby być uznawana za wykonanie zobowiązania, nie zaś za przejaw woli nawiązania nowego stosunku pracy o zmienionym układzie podmiotowym. Pytanie jednak brzmi, czy subiektywna ocena wykonawcy określonych czynności nie powinna ustąpić wobec priorytetowych kryteriów obiektywnych? Wykonanie zobowiązania to zachowanie zgodne z jego treścią, która wynika zarówno z oświadczeń woli, jak i z ustawy bądź zasad współżycia społecznego czy zwyczaju (art. 56 k.c.). Odnosząc się do treści oświadczeń woli, dowieść można co najwyżej tego, co pracownik ma świadczyć (do jakiego rodzaju pracy się zobowiązał). Szczególne zaś warunki świadczenia, odpowiadające treści zatrudnienia pracowniczego, wyznacza ustawa. Zachowanie dłużnika będzie mogło zostać uznane za wykonanie zobowiązania jedynie wówczas, gdy odpowiada ono treści czynności prawnej, na którą równorzędnie składają się oświadczenie woli, ustawa, zasady współżycia społecznego i ustalone zwyczaje ${ }^{24}$. Przepis art. 56 k.c., a dalej art. 354 k.c. dają podstawy do przyznania priorytetu normatywnej ocenie

21 Por. wyroki Sądu Najwyższego: z 5 listopada 1998 roku, I PKN 415/98, OSNP 1999, nr 24, poz. 780; oraz z 18 września 2019 roku, I PK 142/18, OSNP 2020, nr 9, poz. 88.

22 Wykładnia ta jest akceptowana w przypadku zmian treści stosunku pracy dokonanych per facta concludentia. Por. wyroki Sądu Najwyższego: z 18 listopada 2014 roku, II PK 2/14, LEX nr 1621335; z 13 września 2016 roku, I PK 190/15, LEX nr 2106825.

23 Z. Radwański, Wykładnia oświadczeń woli..., s. 79.

24 Por. między innymi wyrok Sądu Najwyższego z 18 września 2019 roku, I PK 142/18, OSNP 2020, nr 9, poz. 88 . 
zachowania dłużnika. Czynności wykonywane na rzecz osoby trzeciej na warunkach pracowniczego podporządkowania nie stanowią wykonania pracy zgodnie z umową (na rzecz pozornego pracodawcy), gdyż nie odpowiadają treści zobowiązania wynikającego z pierwotnie zawartej umowy o pracę.

Nie ulega wątpliwości, że zachowanie pracownika, oceniane w danym kontekście sytuacyjnym, w szczególności przez dopuszczenie do pracy i jej faktyczne wykonywanie, może świadczyć o dorozumianym złożeniu oświadczenia woli25. Przyjęcie, że wola nawiązania stosunku pracy może być wyrażona w dowolnej formie, także przez zachowanie pracownika i pracodawcy, jest uzależnione od dokonania obiektywnej oceny faktów jako oświadczeń woli, którym towarzyszy normatywna treśćc ${ }^{26}$. Za przyjęcie obiektywnej metody wykładni zarówno przy ustaleniu złożenia, jak i treści oświadczeń woli przemawia pewność obrotu, a co za tym idzie pewność prawa. Bez normatywnych kryteriów oceny zachowania stron nie sposób przypisać im funkcji oświadczenia woli, a zarazem nawiązania stosunku zobowiązaniowego per facta concludentia. Rola obiektywnej metody wykładni nabiera dodatkowego znaczenia wówczas, gdy doniosłość prawna oświadczeń woli nie wpływa jedynie na sytuację odbiorcy oraz nadawcy, lecz wiąże się również z obowiązkami wobec osób trzecich, w tym wobec państwa (tu: konsekwencje fiskalne nawiązania rzeczywistego stosunku pracy). Normatywne przypisanie faktom znaczenia oświadczenia woli kreującego stosunek pracy znajduje swoje uzasadnienie także w treści art. $22 \S 1^{1}$ k.p. Gdy umowa faktycznie jest wykonywana $\mathrm{w}$ warunkach wskazujących na stosunek pracy, to takie ustalenie, a nie treść oświadczeń, decyduje o charakterze łączącego strony stosunku prawnego ${ }^{27}$. Analizowane z perspektywy całokształtu okoliczności (art. $65 \S 1$ k.c.) zachowanie osoby świadczącej pracę na rzecz osoby trzeciej może być potraktowane jako oświadczenie woli (art. 60 k.c.) stanowiące podstawę nawiązania stosunku pracy (art. 11 k.p.), jeśli tylko owa praca jest, w obiektywnej ocenie, wykonywana na warunkach wskazanych w art. $22 \S 1$ k.p. (art. 56 k.c. w związku z art. $22 \S 1^{1}$ k.p.).

Powyższy wywód pozwala na przyjęcie, że zachowanie pracownika, weryfikowane z perspektywy normatywnej, ex post względem formalnie zawartej niepozornej umowy o pracę może świadczyć o wtórnym, faktycznym zatrudnieniu bezpośrednio u osoby trzeciej, na której rzecz praca jest wykonywana.

Do rozważenia pozostaje kwestia oceny następczego względem złożonego oświadczenia woli zachowania pracodawcy, akceptujcego stan rzeczy, w którym formalnie zatrudniony przez niego pracownik w rzeczywistości świadczy pracę

25 Por. wyroki Sądu Najwyższego: z 31 sierpnia 1977 roku, I PRN 112/77, LEX nr 14418; z 5 listopada 2003 roku, I PK 633/02, OSNP 2004 nr 20, poz. 346; z 7 kwietnia 2009 roku, I PK 215/08, OSNP 2010, nr 23-24; z 6 października 2004 roku, I PK 488/03, OSNP 2005, nr 10, poz. 145; z 8 czerwca 2010 roku, I PK 16/10, LEX nr 607243.

26 O obiektywnej wykładni oświadczeń woli wyrażanych w postaci niejęzykowej zob. Z. Radwański, Wyktadnia oświadczeń woli..., s. $166 \mathrm{n}$.

27 Por. wyroki Sądu Najwyższego z 29 listopada 2017 roku, I PK 358/16, LEX nr 2433081; z 3 czerwca 2008 roku, I PK 311/07, OSNP 2009, nr 19-20, poz. 258. 
podporządkowaną osobie trzeciej. Sytuacja ta wydaje się sprzeczna z podstawowym założeniem, że pracownik w jednym stosunku pracy nie może mieć dwóch pracodawców (art. 3 k.p.). Sprzeczność ta jest jednak pozorna. Przyjęta konstrukcja modyfikacji stosunku prawnego w czasie wskazuje, że pracownik nie pozostaje jednocześnie w stosunku pracy z dwoma podmiotami, lecz w toku wykonywania pracy doszło do faktycznej zmiany po stronie pracodawcy.

Oceniając zachowanie pozornego pracodawcy jako obiektywny przejaw woli, można przyjąć, że doszło do zakończenia pierwotnego stosunku pracy w sposób dorozumiany ${ }^{28}$. Sam fakt niewykonywania umowy nie może świadczyć o jej nieważności, aczkolwiek może być wskazaniem do przyjęcia, iż stosunek zobowiązaniowy ustał. Przy takiej interpretacji zasadne byłoby przyjęcie, że wraz z konkludentnym rozwiązaniem stosunku pracy został nawiązany nowy stosunek prawny o odmiennym układzie podmiotowym. Określenie momentu ustania formalnie zawartego stosunku pracy wymagać będzie dogłębnej analizy zachowań stron z perspektywy spełnienia kryteriów art. $22 \S 1$ k.p. ${ }^{29}$

Ustalenie faktycznej realizacji pracy na rzecz podmiotu innego niż formalny pracodawca warto także skonfrontować z przepisem art. $23^{1}$ k.p. Zastąpienie „zatrudnienia zewnętrznego" zatrudnieniem bezpośrednim może stanowić argument za pozornością umowy między przedsiębiorcami, gdyż de facto nie doszło do zlecenia zadań, a umowa służyła realizacji innych celów bądź za następczą, dorozumianą zmianę kontraktu. Zachowanie pracodawcy, interpretowane z perspektywy stosunku pracy jako zaprzestanie zatrudnienia (a w konsekwencji niewykonywanie formalnie zleconej usługi jako pracodawca zewnętrzny), zestawione z kontynuowaniem tej działalności przez pierwotnie zlecającego z wykorzystaniem tej samej siły roboczej nie powinno być traktowane jako transfer w rozumieniu art. $23^{1}$ k.p. Samo kontynuowanie pracy na rzecz innego podmiotu, któremu nie towarzyszy stosowne wyodrębnienie jednostki gospodarczej (części zakładu pracy), nie jest przejściem części zakładu pracy na nowego pracodawcę, czyli sytuacją, w której nadal trwa ten sam (przedmiotowo) stosunek pracy, a zmienia się jedynie pracodawca ${ }^{30}$. Nie można mówić o przejściu części zakładu pracy, gdy realizowane przez pracownika zadania od początku są związane ze składnikami majątkowymi pozostającymi w dyspozycji osoby trzeciej, na której rzecz praca była wykonywana. Tym samym $\mathrm{w}$ analizowanym przypadku nie można zastosować zmiany podmiotowej stosunku pracy z konsekwencjami wynikającymi z art. $23^{1}$ k.p..$^{31}$

28 Por. wyroki Sądu Najwyższego: z 20 lipca 1997 roku, I PKN 232/97, OSNP 1998, nr 10, poz. 306; z 7 lutego 2018 roku, II PK 335/16, LEX nr 2459702.

29 Analogicznie do wskazać przyjętych do oceny przekształcenia umowy, por. wyrok Sądu Najwyższego z 18 września 2019 roku, I PK 142/18, OSNP 2020, nr 9, poz. 88.

30 Por. na przykład wyroki Sądu Najwyższego: z 7 lutego 2018 roku, II PK 335/16, LEX nr 2459702; oraz z 18 kwietnia 2018 roku, II PK 53/17, LEX nr 2549226; oraz wyrok Europejskiego Trybunału Sprawiedliwości z 11 marca 1997 roku w sprawie C-13/95, Ayse Süzen vs. Zehnacker Gebäudereinigung GmbH Krankenhausservice, pkt 13, 15.

31 Por. wyrok Sądu Najwyższego z 28 stycznia 2021 roku, I USKP 4/21 (niepubl.). 


\section{PODSUMOWANIE}

Z przedstawionego wywodu wynika, że stwierdzenie pozorności umowy o pracę, w ramach której praca świadczona jest na rzecz osoby trzeciej, wymaga w pierwszej kolejności ustalenia wspólnego, tajnego porozumienia między pozornym pracodawcą a pracownikiem. Brak zgody pracownika na symulowanie stosunku pracy o określonym układzie podmiotowym wyklucza możliwość zastosowania sankcji z art. $83 \S 1$ k.p. Zgoda pracownika musi być wykazana najpóźniej na chwilę zawarcia umowy. Ocena późniejszego zachowania stron stosunku pracy wymaga uwzględnienia, że - co do zasady — dopuszcza się możliwość zobowiązania pracownika do świadczenia pracy na rzecz osoby trzeciej. Ujawnienie w toku realizacji umowy rzeczywistego podmiotu zatrudniającego przez zintensyfikowanie podporządkowania pracownika bezpośrednio osobie trzeciej nie może być automatycznie uznawane za wyraz pierwotnej, rzeczywistej woli pracownika. Należy w takiej sytuacji uwzględnić ewentualną zmianę treści stosunku prawnego w czasie przez fakty konkludentne w postaci nawiązania rzeczywistego stosunku pracy w odmiennym układzie podmiotowym, szczególnie wówczas, gdy w toku świadczenia pracy ukształtowała się trwała relacja pracowniczego podporządkowania między pracownikiem a osobą trzecią.

\section{THE APPEARANCE OF AN EMPLOYMENT CONTRACT IN THE CASE OF EXTERNAL EMPLOYMENT}

\section{Summary}

The appearance of an employment contract requires a secret agreement between an employer and an employee regarding the simulated activity. It is unacceptable to require an employee to speculate what the actual intentions of the employer are. Employee's consent to the simulated activity needs to be unquestionable. Moreover, it is incorrect to assume that an employee agrees to an apparent employment relationship once he or she enters the contract in good faith by performing work for a third party. The fact of performing work for a benefit other than that of an employer, assessed ex post, may lead to modification of the contract. Rejecting of this perspective in order to invalidate the employment contract due to the suggested appearance should be considered an error in application of law. In particular, in permanent legal relationships, an adaptive interpretation should be conducted, accepting changes that happened in legal relationships over time, including modifications expressed in objectively assessed behavior of the parties to the contract and other persons.

Keywords: apparent declaration of will, external employer, interpretation of contracts, implied employment contract 


\section{BIBLIOGRAFIA}

Lewandowicz-Machnikowska M., Wady oświadczenia woli, [w:] System Prawa Pracy, t. 1. Czesść ogólna, red. K.W. Baran, Warszawa 2017.

Lewaszkiewicz-Petrykowska B., Wady oświadczenia woli w polskim prawie cywilnym, Warszawa 1973.

Lewaszkiewicz-Petrykowska B., [w:] Kodeks cywilny. Komentarz. Część ogólna, red. P. Księżak, M. Pyziak-Szafnicka, Warszawa 2014.

Longchamps de Berier R., Zobowiqzania, Lwów 1938.

Miętek A., Zatrudnienie zewnętrzne a swoboda umów stron stosunku pracy - analiza zjawiska, „Monitor Prawa Pracy” 2015, nr 10.

Piasecki K., [w:] Kodeks cywilny. Księga pierwsza. Część ogólna. Komentarz, Kraków 2003.

Raczkowski M., Pozorność w umownych stosunkach pracy, Warszawa 2010.

Radwański Z., Wykładnia oświadczeń woli składanych indywidualnym adresatom, Wrocław 1992.

Radwański Z., Zagadnienia ogólne wyktadni oświadczeń woli, „Nowe Prawo” 1986, z. 9.

Radwański Z., Gutowski M., Wady oświadczeń woli, [w:] System Prawa Prywatnego, t. 2. Prawo cywilne - część ogólna, red. Z. Radwański, A. Olejniczak, Warszawa 2019.

Ślebzak K., Kontrola przez ZUS ważności umów o pracę stanowiacych tytuł do ubezpieczenia spotecznego - wybrane zagadnienia, „Praca i Zabezpieczenie Społeczne” 2017, nr 2. 